\title{
Transposition
}

Musique et Sciences Sociales

$8 \mid 2019$

Musique : patrimoine immatériel ?

\section{Introduction. Music: Intangible Heritage?}

Elsa Broclain, Benoît Haug and Pénélope Patrix

\section{(2) OpenEdition}

\section{Journals}

Electronic version

URL: http://journals.openedition.org/transposition/4201

DOI: 10.4000/transposition.4201

ISSN: $2110-6134$

\section{Publisher}

CRAL - Centre de recherche sur les arts et le langage

\section{Electronic reference}

Elsa Broclain, Benoît Haug and Pénélope Patrix, «Introduction. Music: Intangible Heritage? »,

Transposition [Online], $8 \mid$ 2019, Online since 15 October 2019, connection on 16 December 2020. URL : http://journals.openedition.org/transposition/4201; DOI : https://doi.org/10.4000/transposition.4201

This text was automatically generated on 16 December 2020.

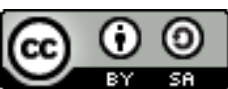

La revue Transposition est mise à disposition selon les termes de la Licence Creative Commons Attribution - Partage dans les Mêmes Conditions 4.0 International. 


\title{
Introduction. Music: Intangible Heritage?
}

\author{
Elsa Broclain, Benoît Haug and Pénélope Patrix
}

Nearly two thirds of the elements inscribed on the UNESCO Intangible Cultural Heritage (ICH) lists in 2018 include a significant musical component. ${ }^{1}$ Traditions such as lkhon $k h o l$, a religious ritual combining dance, music and masks from the community around the Wat Svay Andet Buddhist monastery in Cambodia; as-samer, a singing and dancing practice from Jordan; singing to the accompaniment of the gusle from Serbia; and reggae music from Jamaica, are now listed alongside Greek rebetiko; the sega tambour of Rodrigues Island (both inscribed in 2017); tango of the Rio de la Plata region; the festnoz festive gathering of Brittany; and the tar craftsmanship and performance art in Azerbaijan, to name but a few. In all, on these lists one finds more than 300 practices $^{2}$ in which music plays an important part, most of which also involve forms of celebration, dances, rituals, poetry or know-how. ${ }^{3}$ Indeed, it appears that music holds a key place in the "intangible cultural heritage" of humanity, as inventoried by UNESCO since its 2003 Convention for the Safeguarding of the Intangible Cultural Heritage ${ }^{4}$ (hereinafter referred to as the Convention). 


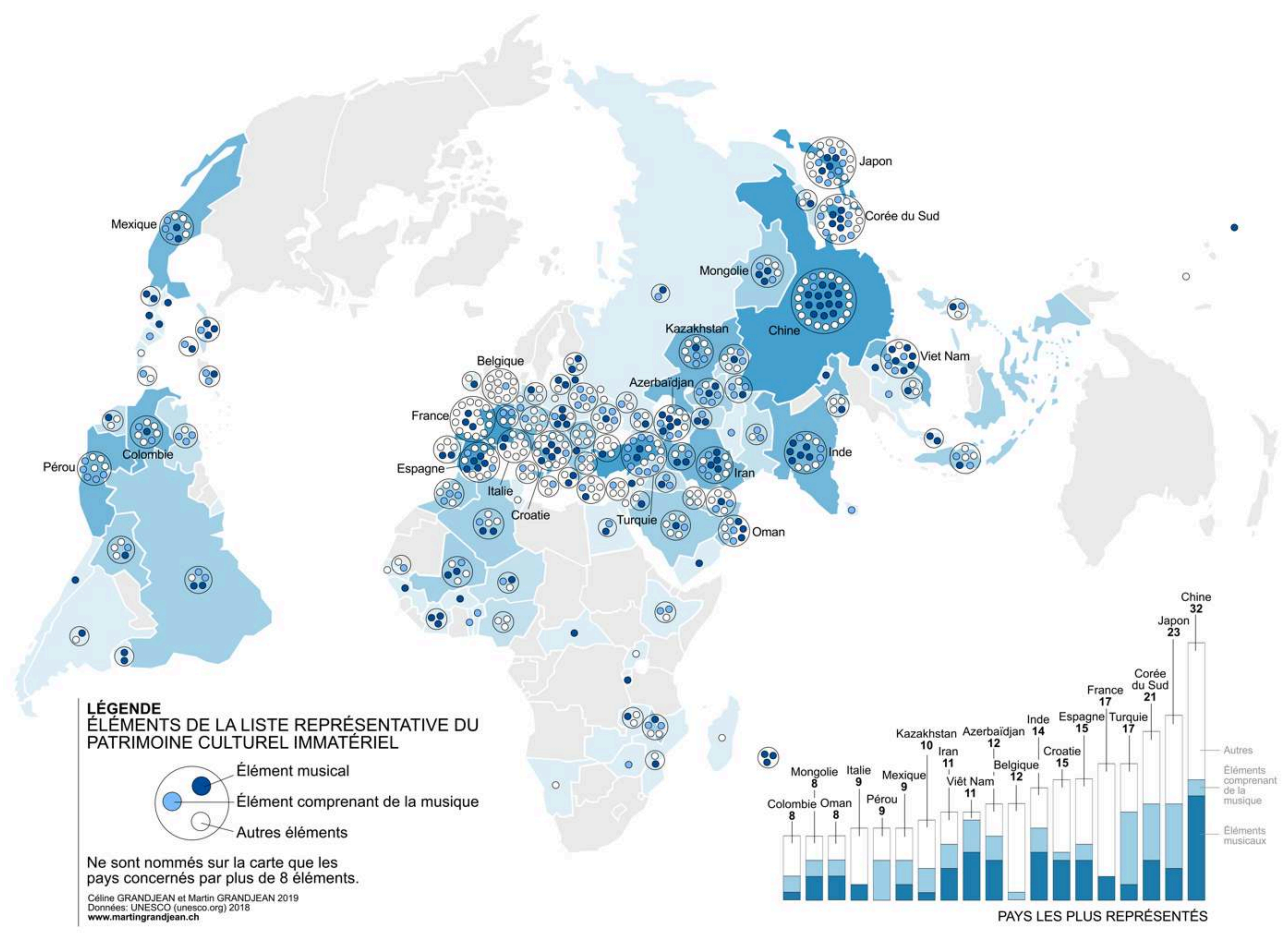

III. 1: Global distribution of ICH elements and the relative proportion of music (CLICK ON “ORIgINAL" TO EXPAND) ${ }^{5}$

2 Does this imply that music is particularly compatible with the concept of "intangible heritage", demonstrating a predisposition to the heritage model put forward by UNESCO? Does music lend itself more easily to the mechanisms of heritagisation than other cultural phenomena? Or does this device merely reflect the pervasiveness of music among social practices around the world? In any case, this observation of the preponderance of music in ICH calls for an examination of ways in which it is defined and perceived in this context, and of the theoretical and historical presuppositions at play. In this regard, although the notion of "intangibility" is above all an institutional and practical distinction, ${ }^{6}$ it echoes the romantic Western tradition, continuing to the present day, of considering music the most "spiritual" of all art forms. " "Intangible cultural heritage" is often presented by UNESCO experts and representatives as a "patrimonial turn", aiming to redress "North-South" imbalance in terms of different conceptions of culture and the elements inscribed worldwide ${ }^{8}$; but might this new category paradoxically reiterate the dominant Western aesthetic paradigm? Does classifying a form of music as "intangible heritage" subjugate it to a situated symbolic system, whereas other traditions, in the West and elsewhere, focus rather on music's rootedness in the human body, in places, instruments and objects? ${ }^{9}$ Let us bear in mind, however, that when UNESCO grants music a certain distinction among the "performing arts" within $\mathrm{ICH}$, it is a matter of its supposed universality rather than because of its intangibility ${ }^{10}$ : intangible heritage, yes, but also and most importantly, heritage of humanity.

3 This prevalence of music in the field of ICH raises the question: what does music do to $\mathrm{ICH}$ ? Due to characteristics considered specific to it, does music prompt a rethinking of the definitions of and ways of making heritage? Does it play a particular role in the "new heritage" 11 and the reorientations introduced by UNESCO in the aim of promoting 
living practices and their practitioners, rather than artefacts? ${ }^{12}$ How does music challenge or reframe this new category, "intangible cultural heritage"?

4 Conversely-and this is the initial assumption the present issue seeks to explore-this new regime of "intangible heritage" seems to have become the dominant paradigm in processes of heritagisation and recognition of musical practices at the international level. Since the ratification of the Convention by UNESCO Member States and its entry into force in 2006, ICH nomination files have flooded in. Indeed, inscription on the UNESCO lists has become a new prospect in the "game of heritagisation" (course à la patrimonialisation $)^{13}$ and a key stake in the recognition of musical and, more broadly, cultural practices around the world. This assumption calls for a world history of musical heritagisation, with a particular interest in the part played by the UNESCO Convention and the new order it has established in the heritage field internationally in this landscape. That is, it also raises the question: what does ICH do to music? How is this paradigm affecting musical practices, denominations and theories, as well as the diversity of music conservation, recognition and safeguarding devices?

of course, the assumption that ICH dominates the field of musical heritagisation does not necessarily imply it has eradicated previously-existing and alternative formulas: classification and action categories such as "traditional music", "regional music", "oral music", "popular music" and "folk music" continue to exist in associations, festivals, libraries, museums, archives, and local, regional and national inventories around the world. It must be said, however-as shown by the articles assembled in this issue-that since being imposed by UNESCO, ${ }^{14}$ the category of "intangible cultural heritage" has infiltrated musical domains (professional or amateur, local or transnational) far beyond the United Nations' scope of action. It has, if not invaded, at least been embraced by museums, festivals and municipalities, adding itself to, if not outright replacing, the current denominations. The safeguarding measures prescribed by the Convention as an international instrument (community consultation and involvement, emphasis on living practices and their practitioners, setting up inventories, and creating archives, scientific studies, museums or other competent organisations) and the values it promotes (universality, equality, respect for human rights and peace, along with celebration of cultural diversity and recognition of minorities ${ }^{15}$ ) have become prescriptive in musical heritagisation practices and local cultural policies, imposing this new heritage paradigm as a worldwide standard ${ }^{16}-$ to the point of exasperating some, who question this new category, ${ }^{17}$ criticise it or attempt to work around it.

6 The assumption that ICH is now one of the main forces driving music heritagisation at the global level urges examination of this phenomenon. Indeed, it raises pressing questions of serious consequence, deserving investigation across the broad spectrum of human and social sciences. Countless practices around the world are concerned by these issues and currently traversed by debates, conflict and attempts at redefinition and resolution in relation to these questions around heritage. This is why it is so important to critically examine this new order and how it is perceived, not only by the musicians and communities concerned, but also by a wide range of actors and institutions in these fields. 


\section{Musical heritagisations in the age of $\mathrm{ICH}$ : a literature review}

7 How have these questions been addressed thus far? Before delving into the specific domain of ICH, it is first important to note the instability of the scope, and even the definition, of "intangible cultural heritage" per se-between researchers, heritage professionals (curators, restorers, museologists, mediators), and musicians and other actors in the music scenes. This instability is maintained by one of the main disjunctures in the field today: the "disconnect" between, on the one hand, the heritagisation of music by conserving its artefacts (instruments, notations, recordings), which are considered the witnesses of its history and the depositories of its "works"; and on the other hand, heritagisation by supporting and revitalising the creation processes, knowledge, skills and social dynamics specific to the practices, particularly applied to so-called traditional, oral, folk and world music. ${ }^{18}$ The first, originating in Western tradition, is implemented by conservation institutions (museums, archives and libraries); the second stems from the "new museologies" and is further extended in the "new heritage" promoted by the UNESCO ICH framework.

This provides key historical perspective, allowing us to replace ICH at the end of a line of conservation and safeguarding processes tracing back at least to the nineteenth century. In this sense, the numerous historical studies on compilations of popular poetry, inventories, museums of music, ${ }^{19}$ collections of scores and recordings ${ }^{20}$ and, more broadly, on musical archives-between romantic folklore, national constructions and emerging sciences ${ }^{21}$-play a de facto part in the history of musical heritagisation. Yet this sweeping statement-inclusive, to say the least-must be counterbalanced with a nominalist approach: applying the idea of "cultural heritage" to music did not occur until late in the twentieth century, and for some time did not extend to anything more than physical media (notated, discographic, organological, etc.), whereas the neologism "heritagisation" did not appear until the early twenty-first century. This reserve in no way invalidates the historical framing of musical heritagisations, as long as we do not completely lose sight of the unique characteristics of today's landscape and its specific vocabulary around heritage, the marker of its historicity.

In 2013, ethnomusicologist Luc Charles-Dominique explored these issues through an original work on the anthropology of the heritagisation of music and art, ${ }^{22}$ combining a re-examination of the institutional history of heritagisations in France since the Revolution with a critical reading of the ICH device and its consequences in various domains. While the article's programmatic conclusion explicitly addresses the field of ethnomusicology, these remarks can nonetheless be applied to all social sciences:

In any case, when it comes to heritage policies and their success, it is clear that studying them is now becoming an essential dimension of ethnomusicological analysis. At stake here are: the representation of identity due to the increased number of levels involved (international, national, local and individual) and their interferences, the dialectics of safeguarding or revitalisation, the paradox of the emergence of a global discourse on the protection of cultural diversity, the effects of heritagisation on the evolution of cultures, the changes that follow their institutionalisation, their being proclaimed "universal", the touristification and "spectacularisation" of these cultural phenomena suddenly pulled out of the shadows and placed in the international spotlight. ${ }^{23}$ 
10 genealogy would therefore require a reorientation of the discipline on a par with the issues at stake, which, while not necessarily beginning with $\mathrm{ICH}$, do seem catalysed by this process. Regarding the French domain, it is not surprising that this work comes from an advocate of ethnomusicology informed by historic anthropology, who has long played an important role in the French folk revival movement, notably with institutions involved in documenting and promoting "traditional" music and dance. Indeed, "intangible heritage" seems to be the latest avatar for the idea of "tradition", stepping in as the leading form of performative reference to the past, or more specifically, way of-legitimately-connecting modern-day practices and objects with those considered historical. ${ }^{24}$ If this assumption is tested in the field of music, revivals appear as particularly relevant objects ${ }^{25}$ : the essential link between the present-day practice and "traditions"-and thus, increasingly, "heritage"-is constantly reasserted, made explicit, argued and negotiated, breeding a diversity of practices ranging from the most cosmopolitan to the most conservative. ${ }^{26}$

is the shift proposed by multiple recent studies on the anthropology of heritage, dealing with globalised musical practices generally articulated on the world music scenes, and therefore separate from the local/global dichotomy discussed above. ${ }^{27}$ Let us bear in mind that while the idea of "heritage" has become widespread in musicological and ethnomusicological publications and events, ${ }^{28}$ and particularly profuse in popular music studies, ${ }^{29}$ some question its epistemic or disciplinary status or guard against it when it does not explicitly emerge from within the field. ${ }^{30}$

12

In terms of the current place of musical practices in the specific domain of "intangible cultural heritage", and vice versa, one observes that of the many studies on the issues involved with the Convention and the ways in which inscriptions on the ICH lists are affecting cultural practices, few have focused their analyses specifically on music. However, in the 2011 collective book Le patrimoine culturel immatériel: enjeux d'une nouvelle catégorie (Intangible Cultural Heritage: Issues with a New Category), a groundbreaking reference on the subject, two of the four case studies presented deal with musical practices and outline preliminary reflections on how this new paradigm intersects with musical practices and denominations. ${ }^{31}$ In the first, Ignazio Macchiarella questions the suitability of the ICH category for music, and-in line with the protagonists of Sardinian canto a tenore-expresses reservations about considering forms of musical expression that exist only "if there is someone in the flesh" like a "disembodied passing on of sound", i.e. "something intangible and immaterial." 32 Carlos Sandroni, on the other hand, examines how the project to safeguard samba de roda has begun to affect the social dynamics within the practice groups. By creating a community that has ended up out-of-sync with practitioners not involved in the initiative-the "real" sambadores-the ICH nomination has led to new conflicts and power dynamics between "bearers", contrary to the project's stated goals of fostering community and cohesion. ${ }^{33}$

Following from these studies, various researchers have examined the transformations brought about by the heritagisation and labelling of musical practices through ICH. Some have closely examined the application processes for inscription on the UNESCO ICH lists and the safeguarding programmes set up in light of the political, social and aesthetic stakes involved. ${ }^{34}$ Others have demonstrated how this meeting of music and ICH has given rise to emerging, hybrid forms of heritagisation, promotion,

Transposition, 8 | 2019 
museification, curating/exhibition and "spectacularisation" of music. ${ }^{35}$ Still others are beginning to analyse the ways in which the performative practices, actors and discourses are reorganising in order to absorb this new order ${ }^{36}$ Nevertheless, analysing the effects of this new heritage regime on music remains in the earliest stages, and this emerging research is limited to specific case studies and geographical areas. Consequently, there is not always dialogue between such studies, limiting the possibilities for developing comprehensive theories on the interactions between music and ICH.

This issue of Transposition seeks to contribute to this field of research through a transnational, comparative approach to the relations between music and "intangible heritage". It brings together case studies and theoretical reflections on multiple cultural areas, drawing on a variety of fields and disciplines. It follows from several very recent studies in this regard, primarily in the English-speaking and Spanishspeaking domains. Notably, since the release of our call for papers, the proceedings from a conference held in London four years prior were published under the title Music as Heritage: Historical and Ethnographic Perspectives (2018). ${ }^{37}$ This important contribution works from the premise that the 2003 Convention is now a key reference in studies on musical heritage, and examines this heritage model with regard to spheres of musical activity outside the UNESCO scope. It explores the ways in which "musical cultures" are affected by national and international heritage discourses and policies. It also deals with the paradoxical issue of art music practices under threat of extinction and which have received little attention. Published in 2018 in the journal TRANS, the dossier Música y patrimonio cultural en América Latina addresses social, political and identityrelated issues around ICH in the context of Latin American music. The studies it compiles convey the variety of heritagisation processes in Latin America, despite the standardised nature of the safeguarding operations affiliated with ICH and UNESCO. ${ }^{38}$ Finally, the Oxford Handbook of Music Revival-which, as said above, examines revival movements and the part they are playing in recomposing the world's "musical landscapes"-dedicated one of its eight sections to ICH and its music "safeguarding" policies, as a major turning point in the contemporary world of traditional music. ${ }^{39}$

\section{Musical intangible heritage challenged in the field}

Following from these studies, this issue seeks to initiate collective reflection on the singularity and complexity of the intersections between music and "intangible heritage", within the scope practiced by UNESCO and beyond. ${ }^{40}$ Looking closely at the ways in which this notion (and/or the heritage apparatus that comes with it) is implemented, reformulated or contested in the field, and at its points of contact and friction with other categories and modes of action in use, the aim here is to consider: what does ICH do to music and, conversely, what does music do to ICH?

This issue sits at the juncture of these two questions. It includes approaches from the fields of anthropology, ethnomusicology, musicology, history and political science, pertaining to regions of the world that each have their own manner of conceiving, making and promoting music. The seven scientific articles in the thematic dossier, based on case studies, are juxtaposed with three texts that broaden the perspective: an interview of three actors in a heritagisation process; the presentation of a research 
project of particular relevance to our concerns; and an essay on an artistic project that revisits the issues addressed here.

17 Together, the texts present a variety of situations relating to the questions posed above, but from their different vantage points, they all examine the relation between music and ICH:

18 - Most of the cases studied correspond to practices inscribed on one of the UNESCO lists, which are the subject of safeguarding programmes already in effect for some years. This is the case for Andalusian flamenco and Portuguese fado (inscribed in 2010 and 2011), explored by Pedro Félix; Guadeloupean gwoka (2014), examined by par Dominique Cyrille and Florabelle Spielmann, and by Pierre-Eugène Sitchet; Portuguese cante alentejano (2014), studied by Maria do Rosário Pestana and Maria José Barriga; and the Egyptian stick game tahțib (2016), analysed by Séverine Gabry. In these examples, the "inscription" ${ }^{41}$ process is underway-consummate, even-to the point that some authors use terms such as "post-heritage context" or "post-inscription on the UNESCO List" in assessing the variable repercussions. However, these articles reveal that the debates, disagreements or hesitations prompted by applications persist once inscription has been obtained, particularly when it comes to implementing the safeguarding programmes. The examples of cante alentejano and gwoka illustrate well the frictions and frustrations that come forth post-inscription, when certain musicians and their aesthetics find themselves invisibilised by these programmes.

19 - Other authors explore the preparation of an inscription file, piercing straight to the difficulties and potential consequences of an application endeavour and the heritagisation of a musical practice. As opposed to situations in which ICH supports heritagisation processes already firmly in motion and integrated into a local history, the UNESCO application project for Catalan rumba, examined here by Arnauld Chandivert and Hervé Parent, arises in a context where "safeguarding" the music was not an issue. The initiative therefore raises new questions about the definition of rumba and the gypsy community.

20 - Some practices are not candidates for the UNESCO lists but are engaged in local heritagisation systems that use the designations and some of the tools and modalities of action of ICH. This is the case for Brazil's folia de reis, declared an element of "intangible cultural heritage" by the Conselho Estadual do Patrimônio Cultural of the state of Minas Gerais, in accordance with the federalised system of Brazilian inventories. Here, community consultation, as prescribed by $\mathrm{ICH}$, becomes a criterion for the assessment of local policies by Lúcia Campos, who examines the question of consent among folia practitioners, that is, their approval of the recognition and safeguarding measures proposed by the institutions.

21 - Finally, some practices undertake separate initiatives or protest actions, while also engaging in dialogue with ICH and/or UNESCO. In the case of Columbian champeta, studied by Juan David Montoya Alzate, in protest of disregard for their music and to draw the attention of public authorities, the "bearers", represented by local associations, ultimately start their own initiative to secure recognition of their music as "intangible heritage". In the case of Saharawi music analysed by Violeta Ruano Posada, the inaccessibility of recognition via the UNESCO lists is due to a conflict situation exacerbated by the lack of international recognition of the Saharawi Arab Democratic Republic. Lastly, Rob Casey presents an example of alternative routes to musical "heritagisation", involving the creation of a fake audio-visual archive of the Irish 
avant-garde. Here, it is the author himself who places his case study in dialogue with the political and practical issues around ICH.

What then happens to music? The Egyptian stick game (tahti ib) represents a borderline case insofar as meeting the UNESCO criteria comes hand in hand with the creation of modern tahtib, a martial art in which music, reduced to percussion alone, is no more than an occasional ornamentation. Whereas the file submitted to UNESCO clearly specified the importance of music in tahtiib-Séverine Gabry emphasises its "essential" role in the practice-ironically, it was made "intangible" in the utmost sense when it was relegated to a historical note in a sports manual. However, this elimination of music remains an exception, offset by the vivacity of music in the other articles. The HeritaMus project presented by Pedro Félix, for example, conveys the aesthetic and material benefit of a tool for collaborative management of $\mathrm{ICH}$, which among other things gives performers access to unpublished audio archives of fado and flamenco, and thus to new repertoires and vocal styles. In the case of cante alentejano, ensembles of young singers are emerging as a result of revitalisation actions. They are introducing new styles within traditional practices, and in some cases, achieving unprecedented exposure and performance opportunities, leading to professional careers. Women are occupying spaces once reserved for men and renewing the social dynamics and vocal registers in the polyphonies, revealing interesting intersections for future studies, between the "ICH-isation" of music and gender issues.

New actors, new aesthetics, new scenes. Renewed repertoires, sonorities, poetics, representations and founding stories. We see that far from being disconnected from the everyday reality of musical practices, ICH processes affect them and are affected by them, on different levels. It remains to be seen whether this has a homogenising effect on practices-as feared by many specialists, and contrary to UNESCO's stated aim of promoting "cultural diversity" (although is it not true that a single phenomenon, such as the inclusion of women, of minorities, can have multiple effects?)-or on the contrary, has a diversifying effect on the apparatus, which could be oriented or even instrumentalised according to the situations in which it is used.

This contiguousness between everyday musical practices and heritage practices can be explained in large part by the participatory turn introduced by ICH; indeed, by emphasising community involvement, it invites the practitioners themselves to take part in these heritagisation endeavours. "We are the heritage!" proclaim the Alentejo singers; "The collections are yours/for you", respond the researchers.

Indeed, with ICH, researchers are also finding themselves in new roles, becoming the designated mediators between practitioners and institutions. Indeed, most of the contributing authors for this issue are directly involved in the same safeguarding programmes they are analysing. Engaged as experts and facilitators in the elaboration of projects and files (Cyrille and Spielmann, Parent and Chandivert), or involved in the implementation of safeguarding and promotion actions (Ruano, Félix) or monitoring post-inscription activities (Pestana and Barriga), they also orient the evolution of the musical practices according to their own political or artistic agenda. For Parent and Chandivert, for example, this is how their involvement with gypsy communities and work on changing their (negative) image has led to an initiative aimed at obtaining recognition of rumba and its "conversion" into ICH. In this sense, intangible cultural heritage can be seen as a laboratory for action research, and researchers find themselves analysing fields that they themselves have taken part in creating, renewing 
the ethical, reflexive and critical questions at the core of the disciplines involved. This is one of the questions raised by Violeta Ruano: "How could I develop a project to advance the Saharawi political claims and, at the same time, do a constructive and critical analysis of their musical situation?" By prompting the reinvention of safeguarding resources for communities and tools for research, ICH can be a driving force for scientific innovation, as the HeritaMus project defended by Pedro Félix tends to show.

\section{Ontologies, power dynamics, and fictions of music heritage}

The way in which this issue seeks to articulate the singularity of music within ICH can be summed up in three recurring points ${ }^{42}$ : the "intangibility" of music caught up in these heritagisation processes; the specific intersections between music, power dynamics and territory in this context; and lastly, the performative nature of the heritage constructions at play, conceived as operative fictions.

"A mobile, traveling, powerful, sonorous temple. An intangible temple": with this striking oxymoron, Lúcia Campos attempts to encapsulate how "music and religion structure each other" in folia de reis, and emphasises the inseparability, in the minds of the foliões she studies, of "the people, practices, gestures, voices, verses, instruments, clothing [and] specific places" that make up their folias. Is it relevant here to consider whether some of these components of the musical experience are tangible and others, intangible, and by virtue of what? Given the artificial nature of this dichotomy, the answer is more likely no, yet this remains a probing point in a heritagisation process that, according to the author, tends to impose the "criteria of the "music-object" (of cultural production) on what is primarily a "music-relation" (between the components of a ritual). What Campos fears is that folias de reis turning into "ordinary music groups" that attend "events", perform on stage, produce albums, are commodified by a tourist industry, etc., in short, into groups that play music like any other, would strip folia of its deep ritual meaning-the best possible site for intangibility-along with facets of its singularity, including elements that are "musical" in the strict sense.

Yet even when all the efforts are focused on absolutely tangible objects, as here in the case of an instrument, the viola caipira; and even when heritagisation, as here, produces effects as basic as decontextualising music; in reading the articles brought together in this issue, the theoretical tangible-intangible dichotomy does not seem very useful in analysing these effects, even musically speaking. The aim here is not to deny the vital role of audio-visual and album recording technologies in the heritagisation processes in question, which are catalysing new relations between the tangibility and intangibility of musical experience; but while recordings do appear at key moments in multiple articles, they seem to have been integrated into the musicians' landscapes and practices (with the exception of folia de reis) for long enough not to pose a problem (or constitute a turning point) in ICH. On the contrary, because industrial forms of music have long been integrated and due to the vast corpuses of records available, discographies can be a rich resource for reconsidering, as the HeritaMus project does, the variety of human and non-human actors making up the community of a heritagised musical practice. 
second point involves rearticulating the intersection between music, power dynamics and territory, as brought about by an international heritage device such as ICH. The matter of recognising subaltern groups through the heritagisation of their music is, in particular, central to several articles in this issue. This proves especially critical in territorial struggles, as Ruano shows with regard to the Sahrawi Arab Democratic Republic (SADR) in exile. In the face of non-recognition of its statehood in the political arena, the SADR is asserting its cultural identity through the international safeguarding of its music. Set up as heritage, music is becoming the emblem and memory through which a nation is claiming its inscription in a territory. On another level, the examples of Afro-Columbian champeta and Catalan rumba also show that the heritagisation of a musical practice affirms "a legitimacy, and a right to be present in a city" 43 and more broadly, in a national community. Thus, ICH seems to be assuming its role as a tool for social justice and the recognition of subaltern groups and practices, put forward by UNESCO in its calls for the protection of "cultural diversity". The "ICH system" could then be utilised to offset a power considered to be oppressive: by legitimising the musical practices with which excluded or dominated groups identify, it provides a way of "working around the State", as articulated by Spielmann and Cyrille.

But the system is a double-edged sword. While proclaiming communities' selfdetermination in defining and managing their heritage, UNESCO primarily liaises with States, which maintain total control over the selection of nomination files. The debates over the ICH inscription of gwoka are an eloquent illustration of this dynamic. As a musical symbol of the struggle for independence, gwoka embodied a practice of resistance against French hegemony. While those in support of inscription hoped to reestablish Guadeloupe's position in the international arena, the opponents feared that it would reaffirm the island's subordination to the French State. Indeed, once it has been inscribed-that is to say, approved and legitimised-by the national authorities, what remains of gwoka's power as a form of protest? The ICH instrument-a weapon of resistance or a tool for domination, depending on your vantage point-can thus be wielded both ways politically, and seems to constantly shirk attempts to assign it a defined role.

31 The third and final point is the performative and even fictional nature of heritage constructions. Two surprising examples stand in contrast to the usual perspective on heritagisation phenomena. The first is the performative act by the "bearers" of champeta of declaring their music "the Intangible Cultural Heritage of the city of Cartagena and the historic Calamarí territories" via a "public declaration of the citizens"-see the article by Juan David Montoya. What makes this "declaration" exceptional is that it was made without any legal or institutional basis for its validity, ${ }^{44}$ and yet, it has been effective. Not only has it had the effect of empowering champetúos, by bringing exposure and legitimacy to their cause with this bottom-up action, but at the same time it has sparked popular interest, triggered a public debate, attracted media coverage and, above all, caught the attention of public authorities, demanding "protection" of this highly stigmatised "oral tradition". What this seems to indicate is that, paradoxically, it is in fact outside the official channels that ICH may grant agency to communities. This only reiterates the unifying and/or dissenting power that musical, festive and performative practices provide for the groups that bear themparticularly in contexts of exclusion, oppression and social struggle. 

decision) of any heritagisation endeavour-contrary to a purist or naturalising conception of ICH, which would only see it as an extension of everyday practices. ${ }^{45}$ It reveals the mechanisms of power that separate the act of declaring (symbolic) from the act of decreeing (effective). In a similar vein, it is against these bodies of power that the "fictional archives" of the Irish avant-garde, invented by Jennifer Walshe and her collaborators on the Aisteach project, attempt to resist-see the article by Rob Casey. This hoax can be seen as a borderline case of Nathalie Heinich's analyses of the "making of cultural heritage" (fabrique du patrimoine), where she points out the manufactured dimension of ICH (as with tangible and natural heritage) resulting from operations of (re)configuration ${ }^{46}$; preceded by Eric Hobsbawm's analyses of "invented traditions" ${ }^{47}$ Walshe, however, takes these theories of heritage constructions as an act of invention a step further, making heritagisation a fiction, in the sense of a "possible world". ${ }^{48} \mathrm{As}$ in the case of champeta, this operation is conceived not as impeding reality, a purely symbolic act or fraud (a faking of authority), but as an operative fiction, with strong practical impact, which by forming an hypothesis makes reality more meaningful. The hypothesis is arrived at through a revision of the past-its collective memory-inscribed in the present and oriented towards the future: what if this experimental avant-garde music that remained "underground" had been recorded and preserved? What heritage would it constitute for artists today? What impact would it have had on creative practices? These fictional audio and visual archives do in fact serve as the basis for Walshe's performances, in that she cites them, plays them and draws inspiration from them; thus, they too become performative. Here again, performing a heritage becomes a political act, a demand for recognition and an act of reparation, through the "restoration" of a forgotten musical universe.

Multiple questions around "post-heritage" phenomena remain unresolved here and would merit further development in future research. Does music tend to dissipate in these operations to inventory, pool and promote "intangible" cultural practices? Or does music even tend to become a pretext for broader endeavours? If so, is this cause for concern, in the name of a singularity of music, as presupposed here? Further research on post-ICH issues would be needed to establish and record these transformations, not only in terms of safeguarding measures but also in the weft of musical, vocal and performative realities. Further studies could also, even more than we have here, give voice to the musicians concerned and provide a platform for those who find themselves invisibilised in processes that place value on certain "bearers", musical practices and sound material, necessarily excluding others. Finally, as illustrated by the two texts on gwoka which offer complementary perspectives and a polyphonic dialogue, new research could counterbalance the viewpoint of experts, which is predominate in this issue and often conveys that of the "victors". In short, we hope that the articles compiled herein open new avenues for studies, projects and critical discussions regarding these crucial issues in the field of music today. 


\section{BIBLIOGRAPHY}

"Música y patrimonio cultural en América Latina", TRANS - Revista Transcultural de Música, no. 21-22, 2018 (sibetrans.com/trans, consulté le 19 août 2019).

"Musiques à voir", Cahiers de musiques traditionnelles, no. 16, 2003.

ADELL Nicolas, BENDIX Regina F., BORTOLOTTO Chiara and TAUSCHEK Markus (eds.), Between Imagined Communities and Communities of Practice: Participation, Territory and the Making of Heritage, Göttingen, Universitätsverlag Göttingen, 2015.

ADELL Nicolas et POURCHER Yves (dir.), Transmettre, quel(s) patrimoine(s) : autour du patrimoine culturel immatériel, Paris, Michel Oudiard, 2011.

AMICO Marta, "La fabrique d'une musique touarègue : analyse comparée, du Sahara à la World Music", L’Homme, no. 227-228, 2018, p. 179-208.

Amico Marta, "Labelliser le désert, recomposer le Mali, mixer les diversités du monde : un festival à l'épreuve de la réconciliation", Cahiers d'ethnomusicologie, no. 27, 2014, p. 189-202.

ATERIANUS-OWANGA Alice et SANTIAGO Jorge P. (dir.), Aux sons des mémoires : musiques, archives et terrain, Lyon, Presses Universitaires de Lyon. 2016.

ATERIANUS-OWANGA Alice, "Un Janus à deux visages : patrimonialisations du religieux initiatique et discours de la tradition dans les musiques 'tradi-modernes' du Gabon”, Autrepart, vol. 78-79, no. 2, 2016, p. 103-124.

AUCLAIR Elizabeth and FAIRCLOUGH Graham, Theory and Practice in Heritage and Sustainability: Between Past and Future, London, Routledge, 2015.

AUSTIN John, How to Do Things with Words, Oxford, J.O. Urmson, 1962 (trad. fr. Quand dire, c'est faire, Paris, Seuil, 1970).

BAKER Sarah, ISTVANDITY Lauren and NOWAK Raphaël, "The Sound of Music Heritage: Curating Popular Music in Music Museums and Exhibitions", International Journal of Heritage Studies, vol. 22, no. 1, 2016.

BERLINER David et BORTOLOTTO Chiara, "Introduction : le monde selon l'Unesco", Gradhiva, no. 18, 2013, p. 4-21.

BIGENHO Michelle, STOBART Henry y MÚJICA ANGUlo Richard, "Del indigenismo al patrimonialismo: una introducción al dossier sobre música y patrimonio cultural en América Latina”, TRANS Revista Transcultural de Música, no. 21-22, 2018 (sibetrans.com/trans, consulté le 19 août 2019). BONDAZ Julien, GRAEZER BIDEAU Florence, ISNART Cyril et LEBLON Anaïs, Les vocabulaires locaux du "patrimoine" : traductions, négociations et transformations, Zurich/Berlin, Lit Verlag, 2014.

BONDAZ Julien, ISNART Cyril et LEBLON Anäis (dir.), Civilisations, vol. 61, no. 1, “Au-delà du consensus patrimonial : résistances et usages contestataires du patrimoine", 2012.

BORTOLOTTO Chiara (dir.), Le patrimoine culturel immatériel : enjeux d'une nouvelle catégorie, Paris, MSH, 2011.

BORTOLOTTO Chiara, "Les enjeux de l'institution du patrimoine culturel immatériel”, Culture et Recherche, no. 116-117, 2008, p. 32-34. 
BRANDELLERo Amanda, JANSSEN Susanne, COHEN Sara and ROBERTS Les (eds.), International Journal of Heritage Studies, vol. 20, no. 3, "Popular Music Heritage, Cultural Memory and Cultural Identity", 2014.

BROCLAIN Elsa, “Tango ${ }^{\circledast}$ : enjeux d'une stratégie de promotion territoriale fondée sur la réappropriation d'un patrimoine musical", Questions de communication, vol. 22, no. 2, 2012, p. 123-140.

CAMPOS Lúcia, "Sauvegarder une pratique musicale ? Une ethnographie du samba de roda à la World Music Expo", Cahiers d'ethnomusicologie, no. 24, 2011, p. 143-155.

CANOVA Nicolas, "Perspectives géographiques pour la musique : la mobilisation du flamenco comme ressource territoriale", Carnets de géographes, no. 1, 2010.

CHARLES-DOMINIQUE Luc et DEFRANCE Yves, L'ethnomusicologie de la France : de l'“ancienne civilisation paysanne" à la globalisation, Paris, L'Harmattan, 2009.

CHARLES-DOMINIQUE Luc, "La patrimonialisation des formes musicales et artistiques : anthropologie d'une notion problématique", Ethnologies, vol. 35, no. 1, 2013, p. 75-101.

CIARCIA Gaetano, La perte durable : étude sur la notion de "patrimoine immatériel", Paris, Lahic/Mission à l'ethnologie, 2006.

COHEN Sara, KNIFTON Robert, LEONARD Marion and ROBERTS Les (eds.), Sites of Popular Music Heritage, London, Routledge, 2015.

DAHLHAus Carl, Die Idee der absoluten Musik, Kassel, Bärenreiter, 1978 (The Idea of Absolute Music, Chicago, UCP, 1989).

DERÈZE Gérard, “De la culture populaire au patrimoine immatériel”, Hermès, no. 42, 2005, p. 47-53. DESROCHES Monique, PICHETTE Marie-Hélène, DAUPHIN Claude et SMITH Gordon E. (dir.), Territoires musicaux mis en scène, Montréal, PUM, 2011.

FOURCADE Marie-Blanche (dir.), Patrimoine et patrimonialisation : entre le matériel et l'immatériel, Québec, Presses de l'Université Laval, 2007.

GASNAULT François, "Mouvement revivaliste et patrimoine culturel immatériel : appropriation ou évitement?", In Situ : revue des patrimoines, no. 33, 2017.

GÉRARD Brice, Histoire de l'ethnomusicologie en France : 1929-1961, Paris, L'Harmattan, 2014.

GRANDJEAN Céline and GRANDJEAN Martin, "Mapping UNESCO Intangible Cultural Heritage”, 2016 (martingrandjean.ch/mapping-unesco-intangible-cultural-heritage, mis à jour en 2019, consulté le 17 octobre 2019).

HEINICH Nathalie, La fabrique du patrimoine : de la cathédrale à la petite cuillère, Paris, MSH, 2009.

HOBSBAWM Eric, “Introduction: Inventing Traditions”, HOBSBAWM Eric and RANGER Terence (eds.), The Invention of Tradition, Cambridge, CUP, 1983, p. 1-14.

HOTTIN Christian et VOISENAT Claudie, Le tournant patrimonial : mutations contemporaines des métiers du patrimoine, Paris, MSH, 2016.

KIRSHENBLATT-GIMBLETT Barbara, “Intangible Heritage as Metacultural Production”, Museum International, no. 221-222, 2004, p. 52-65.

KURIN Richard, « Safeguarding Intangible Cultural Heritage: Key Factors in Implementing the 2003 Convention », International Journal of Intangible Heritage, no. 2, 2007, p. 10-20. 
LAVocAT Françoise, La théorie littéraire des mondes possibles, Paris, CNRS, 2010.

LE GUERN Philippe (dir.), Questions de communication, no. 22, "Patrimonialiser les musiques populaires et actuelles", 2012.

LÉOTAR Frédéric, La steppe musicienne : analyses et modélisation du patrimoine musical turcique, Paris, Vrin, 2014.

LOGAN William S., "Globalizing Heritage: World Heritage as a Manifestation of Modernism, and Challenges from the Periphery", JonEs David (ed.), Twentieth Century Heritage: Our Recent Cultural Legacy, Adelaide, University of Adelaide and Australia Icomos, 2002.

MAISONNEUVE Sophie, "L'industrie phonographique et la patrimonialisation de la musique dans la première moitié du XX ${ }^{\mathrm{e}}$ siècle”, Le temps des médias, vol. 22, no. 1, 2014, p. 77-91.

MÈREDIEU Florence de, Histoire matérielle et immatérielle de l'art moderne et contemporain, Paris, Larousse, 2011 [1994], p. 537-538.

NORTON Barley and MATSUMOTO Naomi (eds.), Music as Heritage: Historical and Ethnographic Perspectives, London, Routledge, 2018.

OUALLET Anne, "Perceptions et réutilisations patrimoniales en Afrique : quelques exemples maliens", GRAVARI-BARBAS Maria et GUICHARD-ANGUIS Sylvie (dir.), Regards croisés sur le patrimoine dans le monde à l'aube du XXI es siècle, Paris, PUPS, 2003, p. 74.

PARENT Marie-Christine, "La patrimonialisation et l'appropriation des traditions musicales : quelques exemples brésiliens”, Les cahiers de la Société québécoise de recherche en musique, vol. 11, no. 1-2, 2010, p. 137-147.

PATRIX Pénélope, "Exposer la voix : médiatisations du fado au Musée du Fado de Lisbonne”, GARRIC Jean-Philippe (dir.), Les dimensions relationnelles de l'art : processus créatifs, mise en valeur, action politique, Paris, Éditions de la Sorbonne, 2017, p. 131-170.

PATRIX Pénélope, “Le fado, 'patrimoine immatériel', vivant ou monument ?”, BARBÉRIS Isabelle (dir.), L'archive dans les arts vivants, Rennes, PUR, 2015, p. 148-157.

PRÉVÔT Nicolas, "Ethnomusicologie et recherche-action : le patrimoine musical des Nanterriens", Cahiers d'ethnomusicologie, no. 29, 2016, p. 137-156.

RODA Jessica, "Le patrimoine à la lumière de l'ethnomusicologie : collaboration, implication et réflexivité", Cahiers d'ethnomusicologie, no. 29, 2016, p. 19-35.

RODA Jessica, Se réinventer au présent : les Judéo-espagnols de France : famille, communauté et patrimoine musical, Rennes, PUR, 2018.

RONSTRÖM Owe, “Traditional Music, Heritage Music", BITHELl Caroline and HILL Juniper, The Oxford Handbook of Music Revival, Oxford, OUP, 2014, p. 43-59.

SAMSON Guillaume, "Le maloya au patrimoine mondial de l'humanité : enjeux culturels, politiques et éthiques d'une labellisation", Cahiers d'ethnomusicologie, no. 24, 2011, p. 157-171.

SANDRONI Carlos, "Samba de roda: patrimonio cultural de humanidade", Estudos avançados, $\mathrm{n}^{\circ}$ 69, 2010, p. 373-388.

SMITH Laurajane, Uses of Heritage, New York, Routledge, 2006.

UNESCO, “Convention pour la sauvegarde du patrimoine culturel immatériel”, 2003

(ich.unesco.org/fr/convention, consulté le 5 septembre 2019). 
VESCHAMBRE Vincent, Traces et mémoires urbaines : enjeux sociaux de la patrimonialisation et de la destruction, Rennes, PUR, 2008, p. 73.

WOLF Werner, "Intermediality Revisited: Reflections on Word and Music Relations in the Context of a General Typology of Intermediality”, Word \& Music Studies, vol. 4, no. 1, 2002, p. 13-34.

\section{NOTES}

1. I.e. 24 of the 39 elements inscribed at the last session of the Intergovernmental Committee for the Safeguarding of the ICH held in November 2018 in Port Louis (combined total from both lists: List of Intangible Cultural Heritage in Need of Urgent Safeguarding, and the Representative List). This figure is the result of a filtered search using the keywords "instrumental music", "religious music" and "vocal music" (proposed by the search engine) of all practices inscribed on the UNESCO ICH lists (ich.unesco.org/en/lists, consulted on 19 August 2019).

2. A search with the same three keywords finds 303 elements with a musical component, of the 508 elements inscribed in all.

3. Despite its theoretical ambiguity and the vast variety of phenomena it encompasses here, the category "music" (and its sub-categories "instrumental", "vocal" and "religious") is the operative term in the scope of this search engine. This broadly applied category is employed as such on the UNESCO lists and in the nomination files for inscription on the lists. However, even when "music" plays a key part in an element, the term is never used on its own; it is always interconnected with other components, in the types of practices now widely considered, notably by art and performance theoreticians, to be "intermedial", i.e. at the intersection of multiple forms and media. See wolf Werner, "Intermediality Revisited: Reflections on Word and Music Relations in the Context of a General Typology of Intermediality", Word \& Music Studies, vol. 4, no. 1, 2002, p. 13-34.

4. UNESCO, "Convention for the Safeguarding of the Intangible Cultural Heritage", 2003 (ich.unesco.org/en/convention, consulted on 5 September 2019).

5. GRANDJEAN Céline and GRANDJEAN Martin, "Mapping UNESCO Intangible Cultural Heritage", 2016 (martingrandjean.ch/mapping-unesco-intangible-cultural-heritage, updated in 2019, consulted on 17 October 2019). We wish to thank Martin and Céline Grandjean for their kindness in updating this map.

6. This category does not have an "ontological basis" [sustento ontologico] and serves mainly as a classification for types of heritage not already covered by UNESCO's previous agreements. See BIGENHO Michelle, STOBART Henry y MÚJICA ANGULo Richard, "Del indigenismo al patrimonialismo: una introducción al dossier sobre música y patrimonio cultural en América Latina", TRANS Revista Transcultural de Música, no. 21-22, 2018 (sibetrans.com/trans, consulted on 19 August 2019). Thus, it is for operative purposes that it artificially distinguishes between tangible and intangible dimensions of heritage. See preface by Laurier Turgeon and the introduction of FOURCADE Marie-Blanche (dir.), Patrimoine et patrimonialisation: entre le matériel et l'immatériel, Québec, Presses de l'Université Laval, 2007.

7. At least "art music", which the dominant aesthetic ideology has placed on the side of spirit, idea, or even the absolute. See the review by: DAHLHAUS Carl, Die Idee der absoluten Musik, Kassel, Bärenreiter, 1978 (The Idea of Absolute Music, Chicago, UCP, 1989). With the notion of "the ineffable", Vladimir Jankélévitch (La musique et l'ineffable, Paris, Colin, 1961) offers an extension of this idea which in several respects aligns with that of "intangibility". On the reach of this idealistic aesthetic beyond the field of music, notably with the emergence of abstraction in the visual arts at the dawn of the twentieth century, see MÈREDIEU Florence de, Histoire matérielle et immatérielle de l'art moderne et contemporain, Paris, Larousse, 2011 [1994], p. 537-538. 
8. Notably to redress the imbalance between "monumental" cultures and "performative" cultures, in order to offset the unequal (strikingly Western-centric) global distribution of tangible heritage. See the reports by the members of UNESCO's intergovernmental committees in charge of drafting and ratifying the Convention, and the reports by the groups of experts and institutional actors in charge of implementing it and establishing the ICH lists at regional or national levels, which can be consulted on the institutions' websites. For a historical-critical analysis, see also LOGAN William S., "Globalizing Heritage: World Heritage as a Manifestation of Modernism, and Challenges from the Periphery", Jones David (ed.), Twentieth Century Heritage: Our Recent Cultural Legacy, Adelaide, University of Adelaide and Australia Icomos, 2002 ; and BERLINER David et воRтоLотто Chiara, "Introduction: le monde selon l'Unesco", Gradhiva, no. 18, 2013, p. 4-21.

9. In addition to the wide ontological variety of practices falling outside the domain of Western art music (whether labelled "traditional", "popular", "folk" music, etc.) we are also thinking of the epistemological shifts introduced in art music by avant-gardists and experimental arts (particularly the "primitivist" movement), as well as the science and technologies of sound, inclined towards explicitly working the tangibility of sound-considered a parameter as such-and the tools, bodies and acts involved in production.

10. "Music is perhaps the most universal of the performing arts and is found in every society, most often as an integral part of other performing art forms and other domains of intangible cultural heritage". See the list of domains and definitions provided on the UNESCO website (https://ich.unesco.org/en/performing-arts-00054, consulted on 19 August 2019).

11. On "new heritage", the "patrimonial turn" (tournant patrimonial) and the new conceptions of and ways of making heritage that have taken hold in the world since the 1970s, see for example AUCLAIR Elizabeth and FAIRCLOUGH Graham, Theory and Practice in Heritage and Sustainability: Between Past and Future, London, Routledge, 2015 ; and HotTIN Christian et voISENAT Claudie, Le tournant patrimonial : mutations contemporaines des métiers du patrimoine, Paris, MSH, 2016.

12. The Convention for the Safeguarding of the $\mathrm{ICH}$, its underlying principles, and its implementation and effects have already been the subject of much controversy and numerous critical analyses. These issues have been of major concern for field anthropologists and museum and heritage professionals not only since the Convention's adoption by UNESCO in 2003 and entry into force in 2006, but also previously, with the premises of the Recommendation on the Safeguarding of Traditional Culture (1989) and the Proclamation of masterpieces of the oral and intangible heritage of humanity (2001-2005). On the new category of thought and action imposed by this device internationally, the epistemological problems it poses, and its potential adverse effects, see BORTOLOTTо Chiara, "Introduction: le trouble du patrimoine culturel immatériel ", BORTOLOTTO Chiara (dir.), Le patrimoine culturel immatériel: enjeux d'une nouvelle catégorie, Paris, MSH, 2011, p. 21-43, and in this book the chapters from Dorothy Noyes and Jean-Louis Tornatore ; CIARCIA Gaetano, La perte durable : étude sur la notion de "patrimoine immatériel", Paris, Lahic/Mission à l'ethnologie, 2006; KIRSHENBLATT-GIMBLETT Barbara, "Intangible Heritage as Metacultural Production", Museum International, no. 221-222, 2004, p. 52-65. On ICH's impact on the actors and processes involved in transmission, see ADELL Nicolas et POURCHER Yves (dir.), Transmettre, quel(s) patrimoine(s) : autour du patrimoine culturel immatériel, Paris, Michel Oudiard, 2011. For the critical heritage studies perspective, see SMITH Laurajane, Uses of Heritage, New York, Routledge, 2006. On the issue of participation and its ambiguities, see ADELL Nicolas, BENDIX Regina F., BORTOLOTTO Chiara and TAUSCHEK Markus (eds.), Between Imagined Communities and Communities of Practice: Participation, Territory and the Making of Heritage, Göttingen, Universitätsverlag Göttingen, 2015. On the subject of the shift from monuments to practices that the ICH category attempts to make, approaches focused on heritage "bearers" rather than the preservation of objects, and the difficulty of implementing these new directives, see HEINICH Nathalie, La fabrique du patrimoine : de 
la cathédrale à la petite cuillère, Paris, MSH, 2009 ; and KURIN Richard, "Safeguarding Intangible Cultural Heritage: Key Factors in Implementing the 2003 Convention", International Journal of Intangible Heritage, no. 2, 2007, p. 10-20.

13. OUALLET Anne, "Perceptions et réutilisations patrimoniales en Afrique : quelques exemples maliens", GRAVARI-BARBAS Maria et GUICHARD-ANGUIS Sylvie (dir.), Regards croisés sur le patrimoine dans le monde à l'aube du XXI siècle, Paris, PUPS, 2003, p. 74.

14. DERÈZE Gérard, "De la culture populaire au patrimoine immatériel”, Hermès, n 42,2005 , p. 47-53.

15. These values correspond to the "spirit of the Convention" as phrased in the Operational Directives for the Implementation of the Convention for the Safeguarding of the Intangible Cultural Heritage (UNESCO 2018 [2008], paragraph 91c), the document serving as the manual for the Convention's concrete implementation-often referred to as the "UNESCO ideology".

16. The Convention does have prescriptive force, imposing itself over national, regional or local standards, in the sense that it is the UNESCO committees who decide whether to accept or refuse a nomination, and the nominated practices must comply in order to meet the inscription criteria -a concern often raised by the experts in charge of processing nomination files. See BERLINER et BORTOLOTTO, "Introduction : le monde selon l'Unesco".

17. On this point, see BONDAZ Julien, ISNART Cyril et LEBLON Anais (dir.), Civilisations, vol. 61, no. 1, "Au-delà du consensus patrimonial : résistances et usages contestataires du patrimoine", 2012. However, the dossier does not include music examples.

18. Two events in 2009, a study day entitled "Patrimoine musical du XX $\mathrm{X}^{\mathrm{e}}$ siècle" (Musical Heritage of the Twentieth Century, coordinated by Thierry Maniguet, Cité de la musique, Paris, 6 April 2009) and a conference "Patrimoines musicaux : circulation et contacts" (Musical Heritage: Circulation and Contacts, coordinated by Monique Desroches, Université de Montréal, 29 October-1 November 2009), illustrate particularly well this polarisation within the francophone sector. The first, organised at the Cité de la musique de Paris by a curator at the Musée de la musique, focused exclusively on the conservation, restoration and safeguarding of musical instruments, technologies and objects. The second, organised by an ethnomusicologist at the Université de Montréal, gravitated around practices and processes relating to performance, identity, heritagisation and touristification. Present in the titles of both events, the "heritage" category was hardly questioned let alone criticised. In this regard, it is worth noting the disappearance of the word "patrimoine" in the title of the conference proceedings: DESROCHES Monique, PICHETTE Marie-Hélène, DAUPHIN Claude et SMITH Gordon E. (dir.), Territoires musicaux mis en scène, Montréal, PUM, 2011.

19. See for example the dossier: "Musiques à voir" des Cahiers de musiques traditionnelles, no. 16, 2003.

20. On the album industry's establishment of a musical heritage in the domain of classical music and on the advent of the "heritage-object of enjoyment", see MAISONNEUVE Sophie, "L'industrie phonographique et la patrimonialisation de la musique dans la première moitié $\mathrm{du} \mathrm{XX}$ siècle", Le temps des médias, vol. 22, no. 1, 2014, p. 77-91.

21. Singularly, compared musicology and then ethnomusicology. In the French domain, see CHARLES-DOMINIQUE Luc et DEFRANCE Yves, L'ethnomusicologie de la France: de l'“ancienne civilisation paysanne" à la globalisation, Paris, L'Harmattan, 2009; and GÉRARD Brice, Histoire de l'ethnomusicologie en France : 1929-1961, Paris, L'Harmattan, 2014.

22. CHARLES-DOMINIQUE Luc, "La patrimonialisation des formes musicales et artistiques: anthropologie d'une notion problématique", Ethnologies, vol. 35, no. 1, 2013, p. 75-101.

23. Ibid., p. 96 (our translation). Let us qualify by saying that a significant share of the musical genres being heritagised had, in 2013, already achieved international renown and dissemination in the context of world music. 
24. See notably: TORNATORE Jean-Louis, «Du patrimoine ethnologique au patrimoine culturel immatériel : suivre la voie politique de l'immatérialité culturelle », BORTOLOTTO (dir.), Le patrimoine culturel immatériel, p. 213-232.

25. It is precisely in reference to musical revivals that Swedish ethnologist Owe Ronström, in his recent chapter for the Oxford Handbook of Music Revival, seeks to theorise the shift from the notion of "tradition" to that of "heritage", understood as a "new mode of cultural production", thus extending beyond the scope of conservation and promotion. RONSTRÖM Owe, "Traditional Music, Heritage Music", BITHELl Caroline and HILl Juniper, The Oxford Handbook of Music Revival, Oxford, OUP, 2014, p. 43-59.

26. See notably, in connection with our main subject: GASNAULT François, "Mouvement revivaliste et patrimoine culturel immatériel : appropriation ou évitement?", In Situ : revue des patrimoines, no. 33, 2017.

27. See, for example: AMIco Marta, "La fabrique d'une musique touarègue : analyse comparée, du Sahara à la World Music", L'Homme, no.227-228, 2018, p. 179-208; "Labelliser le désert, recomposer le Mali, mixer les diversités du monde : un festival à l'épreuve de la réconciliation", Cahiers d'ethnomusicologie, no. 27, 2014, p. 189-202; ATERIANUS-OWANGA Alice et SANTIAGo Jorge P. (dir.), Aux sons des mémoires: musiques, archives et terrain, Lyon, Presses Universitaires de Lyon. 2016 ; ATERIANUS-OWANGA Alice, "Un Janus à deux visages: patrimonialisations du religieux initiatique et discours de la tradition dans les musiques "tradi-modernes" du Gabon", Autrepart, vol. 78-79, no 2, 2016, p. 103-124.

28. To the extent that researchers ironically speak of "heritage inflation" (inflation patrimoniale). Among the many recent publications, let us note these three illustrating a range of situations: a naturalising use of the "heritage" category; a use based on the analysis of processes, making no claim of criticality; and lastly, a performative use wherein it is the researcher who determines the "heritageness" (patrimonialité) of what he archives and promotes: LÉOTAR Frédéric, La steppe musicienne : analyses et modélisation du patrimoine musical turcique, Paris, Vrin, 2014; RODA Jessica, Se réinventer au présent: les Judéo-espagnols de France: famille, communauté et patrimoine musical, Rennes, PUR, 2018; and PRÉVôT Nicolas, "Ethnomusicologie et recherche-action: le patrimoine musical des Nanterriens", Cahiers d'ethnomusicologie, no. 29, 2016, p. 137-156.

29. Possibly indicating the "heritage" category's particular resonance in this field, three collective works were published within a brief interval: LE GUERN Philippe (dir.), Questions de communication, $\mathrm{n}^{\circ}$ 22, "Patrimonialiser les musiques populaires et actuelles", 2012 ; BRANDELLERO Amanda, JANSSEN Susanne, COHEN Sara and ROBERTS Les (eds.), International Journal of Heritage Studies, vol. 20, no. 3, "Popular Music Heritage, Cultural Memory and Cultural Identity", 2014 ; COHEN Sara, KNIFTON Robert, LEONARD Marion and ROBERTS Les (eds.), Sites of Popular Music Heritage, London, Routledge, 2015. Finally, on the subject of the museification of popular music, see BAKER Sarah, ISTVANDITY Lauren and NOWAK Raphaël, "The Sound of Music Heritage: Curating Popular Music in Music Museums and Exhibitions", International Journal of Heritage Studies, vol. 22, no. 1, 2016.

30. See notably: RODA Jessica, "Le patrimoine à la lumière de l'ethnomusicologie : collaboration, implication et réflexivité”, Cahiers d'ethnomusicologie, no. 29, 2016, p. 19-35.

31. In the same book, let us also note Valdimar Hafstein's article on the issue of copyright protection based on a polemic involving El Condor Pasa.

32. MACChiARella Ignazio, "Sauvegarder l'oralité ? Le cas du canto a tenore", BoRtolotto (dir.), Le patrimoine culturel immatériel, p. 167-186 (our translation, quoted section p. 173).

33. SANDRONI Carlos, "L'ethnomusicologue en médiateur du processus patrimonial : le cas de la samba de roda", ibid., p. 233-252.

34. On the political dimension of nomination files, see SANDRONI Carlos, "Samba de roda: patrimonio cultural de humanidade", Estudos avançados, nº6, 2010, p. 373-388. On problems 
posed by the application of the ICH category to forms of popular music, see for example the case of Portuguese fado in PATRIX Pénélope, "Le fado, 'patrimoine immatériel', vivant ou monument ?", BARBÉRIS Isabelle (dir.), L'archive dans les arts vivants, Rennes, PUR, 2015, p. 148-157. On uses of ICH music as a regional resource, see CANOVA Nicolas, « Perspectives géographiques pour la musique : la mobilisation du flamenco comme ressource territoriale », Carnets de géographes, no. 1, 2010; and BROCLAIN Elsa, "Tango ${ }^{\circledR}$ : enjeux d'une stratégie de promotion territoriale fondée sur la réappropriation d'un patrimoine musical", Questions de communication, vol. $22, \mathrm{n}^{\circ} 2,2012$, p.123-140. On power dynamics emerging after inscription and as a result of safeguarding processes, see SAMSON Guillaume, "Le maloya au patrimoine mondial de l'humanité: enjeux culturels, politiques et éthiques d'une labellisation", Cahiers d'ethnomusicologie, no. 24, 2011, p. 157-171; and PARENT Marie-Christine, "La patrimonialisation et l'appropriation des traditions musicales: quelques exemples brésiliens”, Les cahiers de la Société québécoise de recherche en musique, vol. 11, no. 1-2, 2010, p. 137-147.

35. On new forms of museification and curating/exhibition of music and song within ICH, see for example PATRIX Pénélope, "Exposer la voix: médiatisations du fado au Musée du Fado de Lisbonne", GARRIC Jean-Philippe (dir.), Les dimensions relationnelles de l'art : processus créatifs, mise en valeur, action politique, Paris, Éditions de la Sorbonne, 2017, p. 131-170.

36. On the declaration's impact on the professionalisation of musicians and the transposition of local practices onto international scenes, see for example: cAmpos Lúcia, "Sauvegarder une pratique musicale? Une ethnographie du samba de roda à la World Music Expo", Cahiers d'ethnomusicologie, no. 24, 2011, p. 143-155.

37. NORTON Barley and мAтSUMOTO Naomi (eds.), Music as Heritage: Historical and Ethnographic Perspectives, London, Routledge, 2018.

38. Dossier entitled "Música y patrimonio cultural en América Latina", TRANS - Revista Transcultural de Música, n 21-22, 2018 (sibetrans.com/trans, consulted on 19 August 2019).

39. HOWARD Keith, "Reviving Korean Identity through Intangible Cultural Heritage", BITHELL and HILL, The Oxford Handbook of Music Revival, p. 135-159; NORTON Barley, "Music Revival, Ca Trù Ontologies and Intangible Cultural Heritage in Vietnam", ibid, p. 160-181; BITHELL Caroline, "Georgian Polyphony and its Journeys from National Revival to Global Heritage", ibid., p. 573-597.

40. Here, it is worth distinguishing between the notion of "intangible heritage", which has entered into common language and is mainly used descriptively, and the notion of "intangible cultural heritage", reserved primarily for expert use in a normative framework, designating a particular institution of culture connected to UNESCO's international safeguarding system. See BORTOLOTTO Chiara, "Les enjeux de l'institution du patrimoine culturel immatériel", Culture et Recherche, no. 116-117, 2008, p. 32-34.

41. In the sense of integration, balancing or "translation" of the precepts of $\mathrm{ICH}$, when different ways of conceiving, transmitting and perpetuating music interact and collide in the field. On the notion of translation, see BONDAZ Julien, GRAEZER BIDEAU Florence, ISNART Cyril et LEBLON Anaïs, Les vocabulaires locaux du "patrimoine": traductions, négociations et transformations, Zurich/Berlin, Lit Verlag, 2014.

42. This recurrence is partly the result of the discussions when the authors met and shared the first versions of their texts during a working session at EHESS in Paris in May 2017.

43. VESCHAMBRE Vincent, Traces et mémoires urbaines : enjeux sociaux de la patrimonialisation et de la destruction, Rennes, PUR, 2008, p. 73.

44. AUSTIN John, How to Do Things with Words, Oxford, J.O. Urmson, 1962.

45. See KURIN, "Safeguarding Intangible Cultural Heritage".

46. HEINICH, La fabrique du patrimoine.

47. HOBSBAWM Eric, "Introduction: Inventing Traditions", HOBSBAWM Eric and RANGER Terence (eds.), The Invention of Tradition, Cambridge, CUP, 1983, p. 1-14. 


\section{ABSTRACTS}

Music holds a key place in the Intangible Cultural Heritage (ICH) of humanity as inventoried by UNESCO since its 2003 Convention for the Safeguarding of the ICH. More broadly, beyond the United Nations, "intangible heritage" seems to have become the dominant paradigm in processes of heritagisation and recognition of musical practices at the international level. Given the vast scope of this phenomenon, the aim here is to initiate a transnational, comparative approach to the relations between music and "intangible heritage". Looking at the ways in which this notion (and/or the heritage apparatus that comes with it) is implemented, reformulated or contested in the field, and at its interactions with other categories and modes of action in use, this issue of Transposition invites us to ask: what does ICH do to music and, conversely, what does music do to $\mathrm{ICH}$ ?

Most of the studies assembled here deal with practices inscribed on the UNESCO lists, which are the subject of safeguarding programmes already in effect for some years. These "post-heritage" situations are examined in their diversity. Other articles plunge us into the process of preparing an ICH application, piercing straight to the difficulties and potential consequences of heritagising a musical practice. Some practices covered here are not candidates for the UNESCO lists but are engaged in local heritagisation systems that use the designations and some of the tools and modalities of action of ICH. Finally, several articles give voice to heritagisation actions with a separate approach or used as a form of protest.

The singularity of music within ICH can be summed up in three recurring points: the "intangibility" of music caught up in these heritagisation processes; the specific intersections between music, power dynamics and territory in this context, particularly in regard to subaltern practices; and the performative nature of the heritage constructions at play, conceived as operative fictions.

La musique occupe une place de choix au sein du Patrimoine Culturel Immatériel (PCI) de l'humanité tel que le répertorie l'UNESCO depuis sa Convention de sauvegarde de 2003. Plus largement, au-delà des Nations-Unies, le "patrimoine immatériel " semble être devenu le paradigme dominant dans les actions de patrimonialisation et de valorisation des pratiques musicales à l'échelle internationale. Devant l'ampleur de ce phénomène, il s'agit d'engager une approche transnationale et comparative des rapports entre musique et "patrimoine immatériel ». En s'intéressant aux façons dont cette notion (et/ou l'appareil patrimonial qui l'accompagne) est mise en œuvre, reformulée ou contestée sur le terrain, et à ses interactions avec d'autres catégories et modalités d'action en usage, ce numéro de Transposition propose donc de se demander : que fait le PCI à la musique et, inversement, que fait la musique au PCI?

La majorité des études réunies ici s'intéressent à des pratiques inscrites sur les listes de l'UNESCO, qui font l'objet de programmes de sauvegarde entamés depuis plusieurs années déjà. Ces situations « post-patrimoniales » y sont examinées dans leur diversité. D'autres articles nous plongent dans le vif du montage d'un dossier d'inscription, et s'interrogent sur les difficultés et les possibles conséquences de la mise en patrimoine d'une pratique musicale. Certaines des pratiques étudiées ne sont pas candidates auprès de l'UNESCO, mais sont inscrites dans des régimes de patrimonialisation locaux qui reprennent les désignations et certains modes d'action 
et outils afférents au PCI. Enfin, la voix est donnée à des actions de patrimonialisation distinctes ou contestataires.

La singularité de la musique au sein du PCI s'esquisse alors sur trois axes principaux : celui de l'«immatérialité » de la musique prise dans ces processus de patrimonialisation; celui des rapports spécifiques qui s'y articulent entre musique, politique et territoire, notamment au regard de pratiques subalternes; enfin, celui du caractère performatif des constructions patrimoniales en jeu, saisies comme des fictions opératoires.

\section{INDEX}

Mots-clés: musique, patrimoine culturel immatériel, $\mathrm{PCI}$, patrimonialisation, patrimoine musical, Unesco, immatérialité, pratiques musicales subalternes, performativité, postpatrimonialité

Keywords: music, intangible cultural heritage, $\mathrm{ICH}$, heritagisation, heritagization, musical heritage, Unesco, intangibility, subaltern musical practices, performativity, post-heritage

\section{AUTHORS}

\section{ELSA BROCLAIN}

Elsa Broclain est doctorante en Musique, Histoire et Société au Centre de Recherches sur les Arts et le Langage (EHESS) sous la direction d'Esteban Buch. À partir d'une perspective interdisciplinaire, ses travaux s'intéressent aux effets de la patrimonialisation internationale du tango à Buenos Aires et à la traduction locale du paradigme PCI. L'objet de sa thèse est de comprendre les différentes modalités d'appropriations de l'inscription, entre label touristique pour le pouvoir local et instrument de lutte politique pour les communautés de praticiens.

\section{BENOÎT HAUG}

Benoît Haug est chercheur en musicologie \& sciences sociales. De sa thèse dirigée par Xavier Bisaro (CESR, Tours) et Albert Piette (LESC, Nanterre) se profile un livre, La fabrique d'une musique à l'ancienne - sur l'air de « Suzanne un jour » (Lyon : Microsillon, 2020). Entre terrain ethnographique et sous-terrain historique, ses recherches portent essentiellement sur les pratiques actuelles de musiques anciennes. Un intérêt connexe pour les méthodes d'observation et de description de situations l'a conduit à codiriger avec Gwendoline Torterat et Isabelle Jabiot un ouvrage d'anthropologie expérimentale, Des instants et des jours : observer et décrire l'existence (Paris : Pétra, 2017). Il a par ailleurs exercé les fonctions d'ATER pour la section Arts de l'ENS de Lyon après avoir enseigné au département de Musique \& musicologie de l'Université de Tours.

\section{PÉNÉLOPE PATRIX}

Pénélope Patrix est chercheure et enseignante en littératures comparées et en arts, actuellement en postdoctorat au Centre for Comparative Studies (CEC) de la Faculté des Lettres de l'Université de Lisbonne, et associée au Centre d'études et de recherches interdisciplinaires en lettres, arts et cinéma (CERILAC) de l'Université Paris Diderot. Elle a enseigné au sein du cursus de Littérature Comparée de l'Université de Lisbonne, de l'UFR Arts Plastiques et Sciences de l'Art de l'Université Panthéon-Sorbonne et de l'UFR Lettres, Arts et Cinéma de l'Université Paris Diderot, où elle a obtenu son doctorat de Lettres et Arts en 2014. Ses recherches, situées à l'intersection de la littérature comparée, de l'anthropologie et de la musique, portent principalement sur les poétiques et les répertoires de la chanson urbaine, en particulier le fado, le tango et la chanson 
réaliste, du XIX ${ }^{e}$ siècle à nos jours. Elles croisent ce faisant des enjeux propres aux politiques du « patrimoine immatériel », aux articulations entre littérature et musique et à l'intermédialité, aux poésies en performance, et aux représentations de la subalternité dans la chanson, la littérature et les arts. 